\title{
ANALISIS PENGARUH DENSITAS BAHAN BAKAR SILISIDA TERHADAP PARAMETER KINETIK TERAS REAKTOR RSG-GAS
}

\author{
Tukiran S, Surian P, Tagor S. \\ Pusat Teknologi Reaktor dan Keselamatan Nuklir-BATAN, Gedung 80, Serpong email: \\ tukiran@batan.go.id
}

\begin{abstract}
Abstrak
Saat ini RSG-GAS menggunakan elemen bakar silisida 2,96 g U/cc. Untuk meningkatkan waktu operasi reaktor maka akan direncanakan untuk mengganti elemen bakar silisida dengan kerapatan yang lebih tinggi. Keuntungan reaktor dengan bahan bakar kerapatan tinggi adalah dapat lebih efektif dan efisien. Maka perlu dilakukan perhitungan parameter kinetik teras silisida kerapatan tinggi mengingat pengaruhnya sangat penting untuk keselamatan operasi reaktor. Parameter kinetik yang dihitung yaitu fraksi neutron kasip efektif, konstanta peluruhan neutron kasip, umur neutron serempak yang merupakan faktor utama dalam kontrol dan keselamatan. Bahan bakar silisida tipe pelat dengan densitas 2,96 - 4,8 $\mathrm{gU} / \mathrm{cm}^{3}$ digunakan pada teras RSG-GAS untuk menganalisis perhitungan parameter kinetik. Perhitungan sel dilakukan dengan paket program WIMSD-5B dan paket program Batan-2DIFF digunakan untuk perhitungan teras. Hasil perhitungan menunjukkan bahwa harga fraksi neutron kasip turun dengan naiknya densitas bahan bakar. Turunnya nilai parameter kinetik ini tidak mengganggu pergantian bahan bakar ke densitas yang lebih tinggi. Turunnya nilai parameter kinetik rata-rata dari densitas $2,96 \mathrm{gU} / \mathrm{cm}^{3}$ ke $3,55 \mathrm{gU} / \mathrm{cm}^{3}$ adalah $1,3 \%$ sedangkan dari densitas 2,96 $\mathrm{gU} / \mathrm{cm}^{3} \mathrm{ke} 4,8 \mathrm{gU} / \mathrm{cm}^{3}$ adalah $2,2 \%$. Sehingga jika dilakukan pergantian bahan bakar maka ditinjau dari segi neutronik dan parameter kinetiknya tidak akan mengalami perubahan dalam pola operasi reaktor atau manajemen bahan bakar dan tidak akan berpengaruh terhadap keselamatan operasi reaktor.
\end{abstract}

Kata kunci: parameter kinetik, elemen bakar silisida, reaktivitas umpan balik, keselamatan reaktor

\begin{abstract}
Presently, the RSG-GAS reactor uses silicide fuel element of $2.96 \mathrm{~g} \mathrm{U} / \mathrm{cm}^{3}$. For increasing reactor operation time, it is planned to change to higher density fuel in the RSG-GAS core. The advantages of using silicide with higher density is more effective and efficient. So, the kinetic parameter calculation of silicide core with higher density has been carried out, since it has an influence on the reactor operation safety. The calculated kinetic parameters are the effective delayed neutron fraction, the delayed neutron decay constant, prompt neutron lifetime are very important for controlling and reactor operation safety. Silicide fuel of plat type with densities of $2,96 \mathrm{gU} / \mathrm{cm}^{3}-4,80 \mathrm{gU} / \mathrm{cm}^{3}$ that used in the RSG-GAS core to be analyzed the kinetic parameter calutation. Cell calculation is done by WIMSD-5B and core calculation is performed in 2-dimensional neutron diffusion-perturbation method using Batan-2DIFF codes. The calculation showed that the effective delayed neutron fraction, total delay neutron time constant and the prompt neutron lifetime are going down with higher densities. . The result of kinetic parameter silicide fuel of $2,96 \mathrm{gU} / \mathrm{cm}^{3}$ is bigger $1,3 \%$ compare with silicide fuel of $3.55 \mathrm{gU} / \mathrm{cm}^{3}$ and $2.2 \%$ if we compare with $4,80 \mathrm{gU} / \mathrm{cm}^{3}$. So, if it is done the silicide fuel exchange with higher density no significant influence in the RSG-GAS reactor operation pattern, in-core fuel management and reactor operation safety.
\end{abstract}

Keywords: Kinetics parameter, silicide fuel, feedback reactivity, reactor safety 


\section{PENDAHULUAN}

Banyak reaktor riset di dunia saat ini didesain dengan bahan bakar pengkayaan rendah $<20 \%$ karena adanya larangan dari IAEA untuk mengoperasikan reaktor riset dengan pengkayaan tinggi. Pengkayaan rendah membuat reaktor riset tipe pelat seperti RSG-GAS kurang ekonomis karena umur bahan bakar di dalam teras terlalu singkat atau panjang siklusnya kecil. Jika panjang siklus suatu reaktor riset kecil maka reaktor tersebut tidak akan efektif dan efisien sehingga faktor ekonomisnya menurun. Maka salah satu cara untuk meningkatkan nilai ekonomis reaktor riset seperti RSG-GAS adalah dengan meningkatkan densitas bahan bakarnya. Namun sebelum mengganti bahan bakar reaktor tersebut dengan densitas yang lebih tinggi, terlebih dahulu harus dilakukan beberapa kajian dan perhitungan neutronik untuk mengevaluasi parameter keselamatannya.

Reaktor Serba Guna G.A. Siwabessy (RSG-GAS) saat ini beroperasi dengan bahan bakar uranium silisida kerapatan 2,96 $\mathrm{g} / \mathrm{cm}^{3}$. Pada awalnya bahan bakar teras RSG-GAS adalah uranium oksida. Kemudian bahan bakar uranium oksida dikonversi ke uranium silisida dengan muatan dan densitas yang sama. Konversi teras ini sudah tercapai dan saat ini RSGGAS beroperasi dengan bahan bakar uranium silisida dengan densitas $2,96 \mathrm{~g} / \mathrm{cm}^{3}$. Penelitian saat ini yang telah dilakukan adalah desain teras RSG-GAS dengan densitas bahan bakar tinggi. Dimana untuk teras RSG-GAS yang merupakan reaktor riset jenis MTR (Material Testing Reactor) bahan bakar silisida jatuh pilihan pada densitas 3,55 $\mathrm{gU} / \mathrm{cm}^{3}$ atau densitas 4,8 $\mathrm{g} / \mathrm{cm}^{31)}$ [Liem dkk. 1998]. Keuntungan menggunakan bahan bakar uranium silisida dengan densitas tinggi adalah dapat memperpanjang siklus operasi dengan demikian mengurangi jumlah bahan bakar di dalam teras untuk mencapai energi yang sama sehingga lebih ekonomis. Untuk teras dengan densitas tinggi secara neutronik dan kinetik perlu dianalisis sebelum dilakukan konversi bahan bakar ke densitas lebih tinggi namun dalam penelitian ini difokuskan untuk menganalisis pengaruh densitas bahan bakar terhadap parameter kinetik teras RSG-GAS. Dalam analisis tersebut dilakukan perhitungan parameter kinetik teras RSG-GAS untuk bahan bakar silisida densitas $2,96 \mathrm{~g} / \mathrm{cm}^{3}, 3,55 \mathrm{~g} / \mathrm{cm}^{3}$ dan $4,80 \mathrm{~g} / \mathrm{cm}^{3}$. Parameter kinetik sangat penting untuk dianalisis karena sangat berhubungan dengan keselamatan reaktor, khususnya bila terjadi transien dan ekskursi daya, sehingga perlu dilakukan perhitungan yang akurat dengan memperhitungkan beberapa nuklida dapat belah yang terjadi pada teras reaktor.

Dalam makalah ini akan dibahas bagaimana menghitung parameter kinetik seperti, fraksi neutron kasip efektif, $\beta_{\text {eff }}$, konstanta peluruhan neutron kasip $(\lambda)$ dan waktu generasi neutron serempak $(\Lambda)$. Perhitungan dilakukan pada awal siklus (BOC) dan akhir siklus (EOC) untuk melihat pengaruh densitas bakar terhadap parameter kinetik tersebut. Meningkatnya kerapatan uranium diduga dapat menambah besar harga parameter kinetik, sehingga ditinjau dari segi parameter ini reaktor akan lebih mudah dikendalikan bila terjadi ekskursi daya. Dengan dioperasikannya reaktor dari BOC ke EOC maka bertambah fraksi bakar di dalam teras sehingga mengakibatkan penurunan harga parameter kinetik $^{2)}$ [Tukiran dkk 1998] akibat adanya plutonium di dalam teras reaktor sehingga perlu diteliti seberapa besar pengaruhnya terhadap parameter kinetik.

Perhitungan dilakukan dengan menggunakan progam WIMSD-5B dan Batan-2DIFF. Progam WIMSD$5 \mathrm{~B}^{3)}$ [Tukiran dkk 1988] digunakan untuk menggenerasi konstanta kelompok difusi untuk setiap material pada teras reaktor. Program Batan-2DIFF ${ }^{4}$ [Tukiran dkk 2000] digunakan untuk menghitung distribusi fluks neutron regular maupun adjoint. Untuk menentukan umur neutron serempak 
maka terlebih dahulu dilakukan perhitungan kecepatan neutron dengan mengkondensasi 69 kelompok ke dalam 4 kelompok tenaga neutron untuk setiap material teras. Untuk menghitung parameter kinetik, selain data tesebut diperlukan data konstanta kelompok neutron kasip, jumlah fraksi neutron kasip dan jumlah neutron kasip per fisi untuk beberapa nuklida.

Menurut perhitungan neutronik maka teras silisida hingga kerapatan $4,8 \mathrm{gU} / \mathrm{cm}^{3}$ masih aman untuk operasi reaktor dan dapat meningkatkan panjang siklus operasi reaktor yang signifikan ${ }^{5)}$ [Farhan dkk 2009]. Mengingat adanya peningkatan kerapatan uranium yang signifikan, sudah pasti parameter kinetik berubah jika dibandingkan dengan teras silisida kerapatan 2,96 $\mathrm{g} \mathrm{U}^{\mathrm{cm}} \mathrm{cm}^{3}$. Disamping itu, interaksi antara moderator dan bahan bakar di bahan bakar berkerapatan lebih tinggi akan berbeda dengan bahan bakar berkerapatan rendah. Oleh karena itu, perlu dilakukan suatu penelitian untuk menentukan parameter kinetik teras RSGGAS dengan kerapatan lebih tinggi dari yang ada sekarang yaitu $2,96 \mathrm{gU} / \mathrm{cm}^{3}$.

\section{DISKRIPSI TERAS RSG-GAS}

\subsection{Teras RSG-GAS}

RSG-GAS merupakan reaktor jenis MTR (Material Testing Reactor) dengan fluks neutron rerata $2 \times 10^{14} \mathrm{n} / \mathrm{cm}^{2} \mathrm{~s}$. Karena fluks neutron yang tinggi maka teras RSGGAS digunakan untuk produksi radioisotop, iradiasi perangkat bahan bakar reaktor daya, analisis aktivasi neutron dan uji tidak merusak. Fasilitas iradiasi yang dimiliki teras RSG-GAS adalah CIP (Central Irradiation Position), IP (Irradiation Position) Rabbit System, PRTF (Power Ramp Test Facility), tabung berkas neutron dan NTD (neutron transmution doping $)^{6}$ [Tukiran 2002], seperti ditunjukkan pada Gambar 1.

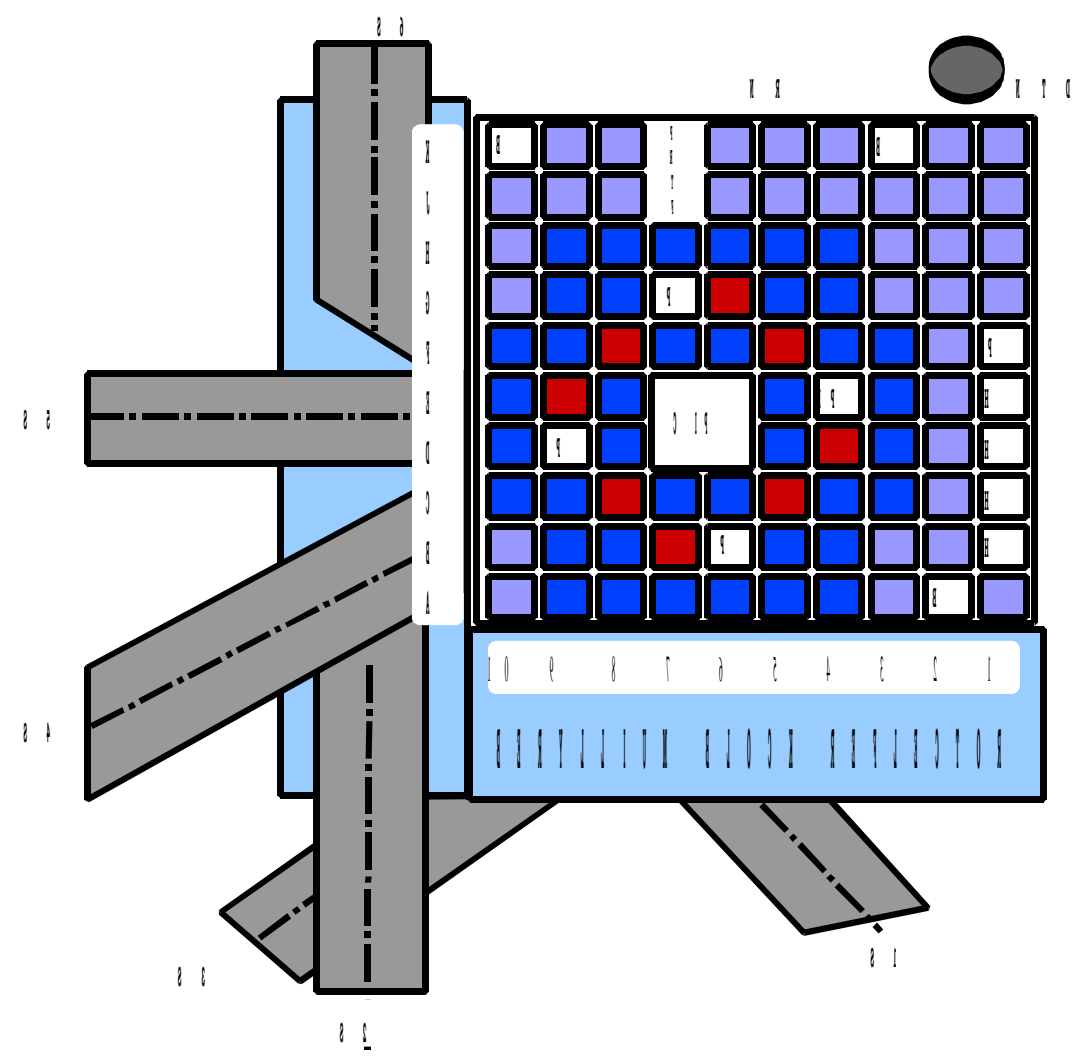

Gambar 1. Teras RSG-GAS dan fasilitas iradiasinya 


\subsection{Bahan Bakar Silisida}

Pemilihan bahan bakar silisida dengan densitas lebih tinggi sebagai bahan bakar alternatif adalah untuk memperpanjang siklus operasi. Disamping itu bahan bakar ini juga mempunyai penghantar panas yang baik dibanding bahan bakar oksida. Berdasarkan peneliti sebelumnya maka pilihan jatuh pada bahan bakar silisida dengan kerapatan 3,55 atau $4,8 \mathrm{~g} / \mathrm{cm}^{3}$. Pada saat ini kerapatan uranium silisida yang dipakai reaktor RSG-GAS adalah 2,96 $\mathrm{g} / \mathrm{cm}^{3}$, sehingga memungkinkan untuk meningkatkan panjang siklus operasi yang signifikan dengan bahan bakar uranium silisida. Sedangkan keuntungan kedua adalah bahan bakar silisida dapat dibakar sampai fraksi bakar $\sim 80 \%$. Tabel 1 menyajikan parameter teras dan jumlah uranium di bahan bakar silisida pada teras RSG-GAS.

Table 1. Spesifikasi teras RSG-GAS berbahan bakar uranium silisida densitas tinggi $^{7)}$ [Tukiran 1998]

\begin{tabular}{|c|c|c|c|}
\hline Parameter Neutronik & $\begin{array}{c}\text { Silisida } \\
2,96 \mathrm{~g} / \mathrm{cm}^{3}\end{array}$ & $\begin{array}{c}\text { Silisida } \\
3,55 \mathrm{~g} / \mathrm{cm}^{3}\end{array}$ & $\begin{array}{c}\text { Silisida } \\
4,8 \mathrm{~g} / \mathrm{cm}^{3}\end{array}$ \\
\hline Jumlah elemen bakar & 40 & 40 & 40 \\
\hline Jumlah Elemen kendali & 8 & 8 & 8 \\
\hline Jumlah penyerap & 8 & 8 & $8+2$ \\
\hline Panjang siklus operasi (MWD/hari) & $614,6 / 20,48$ & $975 / 32,2$ & $1380 / 46$ \\
\hline $\begin{array}{l}\text { Fraksi bakar rerata awal siklus(\% } \\
\left.\text { hilang }{ }^{235} \mathrm{U}\right)\end{array}$ & 23,8 & 32,2 & 34,21 \\
\hline $\begin{array}{l}\text { Fraksi bakar rerata akhir siklus (\% } \\
\left.\text { hilang }{ }^{235} \mathrm{U}\right)\end{array}$ & 30,3 & 40,5 & 42,06 \\
\hline $\begin{array}{l}\text { Fraksi bakar elemen bakar maksimum } \\
\left(\% \text { kehilangan }{ }^{235} \mathrm{U}\right)\end{array}$ & 52,3 & 68,2 & 74,32 \\
\hline $\begin{array}{l}\text { Fraksi bakar elemen kontrol } \\
\left.\text { maksimum (\% kehilangan }{ }^{235} \mathrm{U}\right)\end{array}$ & 56,0 & 71,1 & 77,31 \\
\hline Faktor puncak daya radial maksimum & 1,23 & 1,27 & 1,31 \\
\hline \multicolumn{4}{|l|}{$\begin{array}{l}\text { Parameter Kesetimbangan } \\
\text { Reaktivitas }(\% \Delta k / k) \text { : }\end{array}$} \\
\hline - kondisi panas ke dingin & 0.62 & 0,70 & 0,72 \\
\hline - Xenon setimbang & 3.66 & 3,70 & 3,74 \\
\hline - Perubahan fraksi bakar satu siklus & 2,51 & 3,77 & 4,00 \\
\hline $\begin{array}{l}\text { - eksprimen, partial Xenon override, } \\
\text { dll. }\end{array}$ & 2.97 & 1,07 & 1,5 \\
\hline - Reaktivitas lebih teras & 9.76 & 9,24 & 10,75 \\
\hline - Nilai batang kendali total & $-13,60$ & $-13,05$ & $-13,02$ \\
\hline - Marjin reaktivitas padam & -1.10 & $-1,03$ & $-3,02$ \\
\hline
\end{tabular}

Beberapa reaktor riset di dunia yang menggunakan bahan bakar uranium silisida juga sudah menggunakan densitas tinggi seperti reaktor riset Jepang (JMTR) menggunakan silisida $4,8 \mathrm{gU} / \mathrm{cm}^{3}$, reaktor riset Cina (CARR) menggunakan silisida 
4,3 $\mathrm{gU} / \mathrm{cm}^{3}$, reaktor riset di Pettern menggunakan silisida $4,8 \mathrm{gU} / \mathrm{cm}^{3}$ dan reaktor riset di Australia (OVAL) menggunakan silisida $4,8 \quad \mathrm{gU} / \mathrm{cm}^{3}$.
Selanjutnya data teras dan bahan bakar beberapa reaktor riset di dunia dapat dilihat pada Tabel

Tabel 2. Parameter berbagai jenis teras reaktor riset di dunia ${ }^{8)}$ [Lily 2011]

\begin{tabular}{|c|c|c|c|c|c|c|c|}
\hline \multirow[t]{2}{*}{ Parameter } & \multirow[b]{2}{*}{ JMTR } & \multirow[b]{2}{*}{ CARR } & \multicolumn{5}{|c|}{ Nama Reaktor } \\
\hline & & & HFR & OPAL & CRCN & MPRR & $\begin{array}{l}\text { RSG- } \\
\text { GAS } \\
\end{array}$ \\
\hline Jenis & Tank & Tank & Tank & OP & OP & OP & OP \\
\hline Pendingin & $\mathrm{H}_{2} \mathrm{O}$ & $\mathrm{H}_{2} \mathrm{O}$ & $\mathrm{H}_{2} \mathrm{O}$ & $\mathrm{H}_{2} \mathrm{O}$ & $\mathrm{H}_{2} \mathrm{O}$ & $\mathrm{H}_{2} \mathrm{O}$ & $\mathrm{H}_{2} \mathrm{O}$ \\
\hline Moderator & $\mathrm{H}_{2} \mathrm{O}$ & $\mathrm{H}_{2} \mathrm{O}$ & $\mathrm{H}_{2} \mathrm{O}$ & $\mathrm{H}_{2} \mathrm{O}$ & $\mathrm{D}_{2} \mathrm{O}$ & $\mathrm{H}_{2} \mathrm{O}$ & $\mathrm{H}^{2} \mathrm{O}$ \\
\hline Reflektor & $\begin{array}{l}\mathrm{Be}, \mathrm{D} 2 \\
\mathrm{O}\end{array}$ & $\mathrm{D}_{2} \mathrm{O}$ & $\mathrm{Be}$ & $\mathrm{D}_{2} \mathrm{O}$ & $\begin{array}{l}\mathrm{Be} \\
\mathrm{D}_{2} \mathrm{O}\end{array}$ & $\mathrm{D}_{2} \mathrm{O}$ & $\mathrm{Be}$ \\
\hline Daya termal (MW) & 50 & 60 & 45 & 20 & 20 & 30 & 30 \\
\hline $\begin{array}{l}\text { Fluks neutron termal } \\
\text { rata-rata }\left[10^{14} \mathrm{n} / \mathrm{cm}^{2} . \mathrm{s}\right]\end{array}$ & 4,0 & 4,0 & 2 & 3,82 & 4 & 6,7 & 2,5 \\
\hline Posisi iradiasi & 28 & 25 & 42 & 17 & 19 & 23 & 8 \\
\hline Dimensi teras $(\mathrm{cm})$ & $\begin{array}{l}41,6 x \\
41,6 x \\
75\end{array}$ & - & $\begin{array}{l}72,9 \times \\
750,4 \\
\times 60\end{array}$ & $\begin{array}{l}35 \times 35 \\
\times 61,5\end{array}$ & - & - & $\begin{array}{l}81 X 77,1 \\
\text { X60 }\end{array}$ \\
\hline Jumlah elemen bakar & 24 & 17 & 33 & 16 & 30 & 30 & 40 \\
\hline Jumlah batang kendali & 5 & 4 & 6 & 5 & 8 & 6 & 8 \\
\hline $\begin{array}{l}\text { Tinggi elemen bakar } \\
(\mathrm{mm})\end{array}$ & 750 & 850 & 600 & 700 & 700 & & 625 \\
\hline $\begin{array}{l}\text { Densitas } \mathrm{U}_{3} \mathrm{Si}_{2}-\mathrm{Al} \\
{\left[\mathrm{gram} / \mathrm{cm}^{3}\right]}\end{array}$ & 4.8 & 4,3 & 4,8 & 4,8 & 4,8 & 4,8 & 2,96 \\
\hline Pengkayaan (\%) & 20 & 20 & 19,75 & 19,75 & 20 & 19,75 & 19,75 \\
\hline $\begin{array}{l}\text { Jumlah pelat elemen } \\
\text { bakar }\end{array}$ & 19 & 21 & 20 & 21 & 19 & 20 & 21 \\
\hline $\begin{array}{l}\text { Jumlah pelat elemen } \\
\text { bakar }\end{array}$ & 16 & - & 17 & - & - & 14 & 15 \\
\hline $\begin{array}{l}\text { Dimensi elemen } \\
\text { bakar(mm) }\end{array}$ & $\begin{array}{l}76,2 \mathrm{x} \\
1.200\end{array}$ & $\begin{array}{l}76,2 \times \\
76,2\end{array}$ & $\begin{array}{l}81 x \\
77\end{array}$ & $\begin{array}{l}80,5 x \\
80,5\end{array}$ & $80 \times 80$ & $\begin{array}{l}85,6 \mathrm{x} \\
85,6\end{array}$ & $81 X 77,1$ \\
\hline Tebal meat $(\mathrm{mm})$ & 0,51 & 0,6 & 0,76 & 0,61 & 0,7 & 0,6 & 0,54 \\
\hline Panjang meat (mm) & 760 & 850 & 600 & 615 & 700 & 600 & 600 \\
\hline Lebar meat (mm) & 61,6 & 61,6 & 65 & 65 & 80 & 68,9 & 62,75 \\
\hline $\begin{array}{l}\text { Tebal kelongsong } \\
\text { (mm) }\end{array}$ & 0,38 & 0,38 & 0,38 & 0,37 & 0,4 & 0,4 & 0,38 \\
\hline Jarak antar pelat $(\mathrm{mm})$ & 2,59 & $\begin{array}{l}2,59 \times \\
2 \\
2,57 \times 2\end{array}$ & - & - & 2,7 & 2,3 & 2,55 \\
\hline Absorber & Hf & $\mathrm{Hf}$ & $\mathrm{Cd}$ & $\mathrm{Hf}$ & $\mathrm{AgInCd}$ & $\mathrm{Hf}$ & AginCd \\
\hline Racun dapat bakar & $\begin{array}{l}\text { Kawat } \\
\text { Cd }\end{array}$ & $\mathrm{BKP}$ & & $\begin{array}{l}\text { Kawat } \\
\text { Cd }\end{array}$ & & BKP & - \\
\hline
\end{tabular}




\section{PERHITUNGAN PARAMETER} KINETIK

\subsection{Generasi Tampang Lintang}

Data tampang lintang makroskopis seperti sigma fisi, konstanta difusi untuk tiap inti dapat belah yang memberikan kontribusi dalam pembangkitan neutron kasip diperoleh dari perhitungan sel yang dilakukan dengan paket program WIMSD5B dengan diagram alir program seperti ditunjukkan pada Gambar 2.

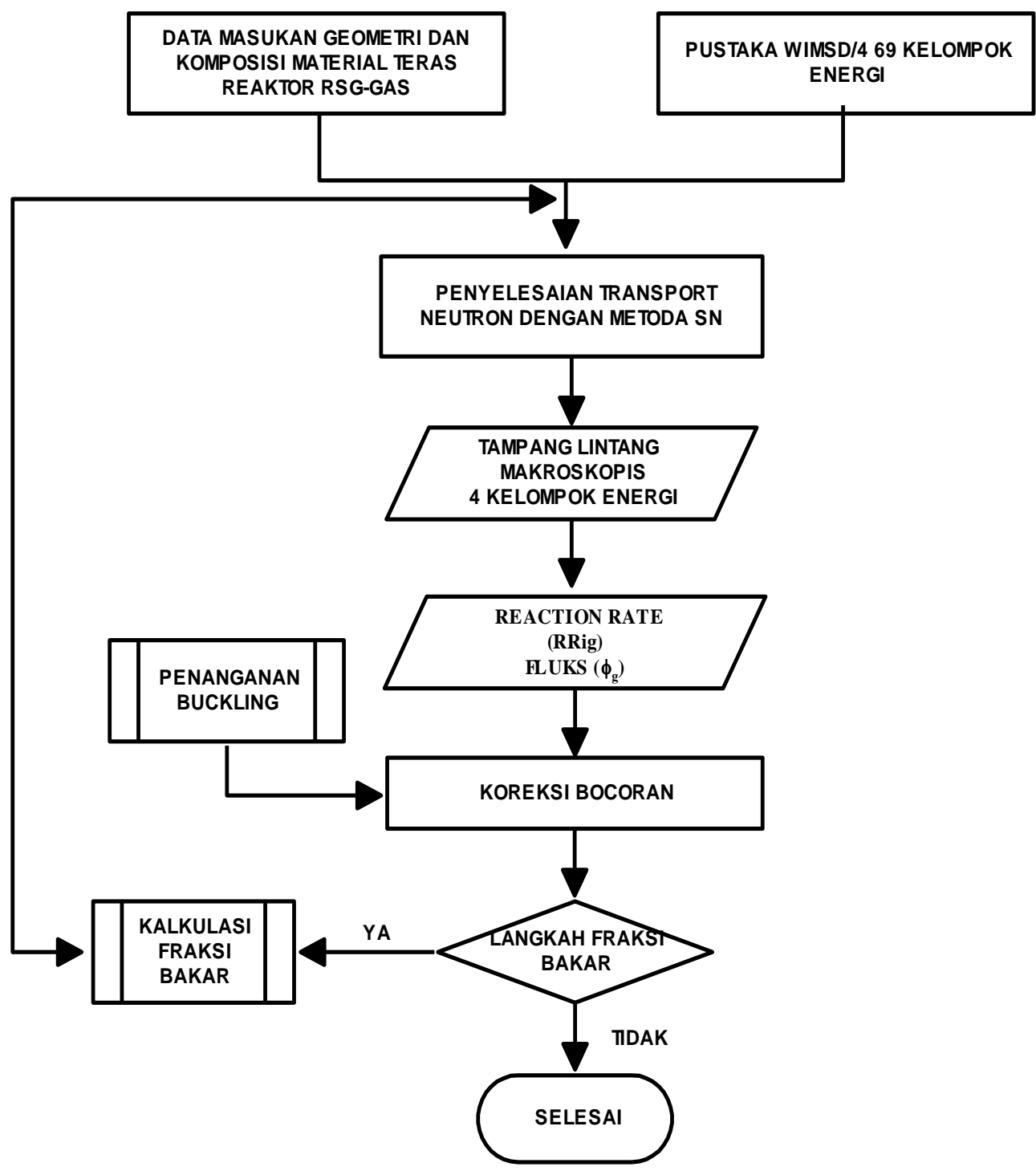

Gambar 2. Diagram alir program WIMSD-5B

Program WIMSD-5B hanya mampu melakukan perhitungan transport neutron satu dimensi. Oleh karena itu daerah aktif elemen bakar dan elemen kendali perlu dimodelkan dalam satu dimensi yang merupakan susunan beberapa slab.

\subsection{Generasi Kecepatan Rerata Neutron}

Perhitungan generasi kecepatan rerata neutron juga dilakukan paket program WIMSD-5B untuk awal siklus teras RSGGAS. Teras setimbang awal siklus dimodelkan dalam satu sel seperti ditunjukkan dalam Gambar 3. 


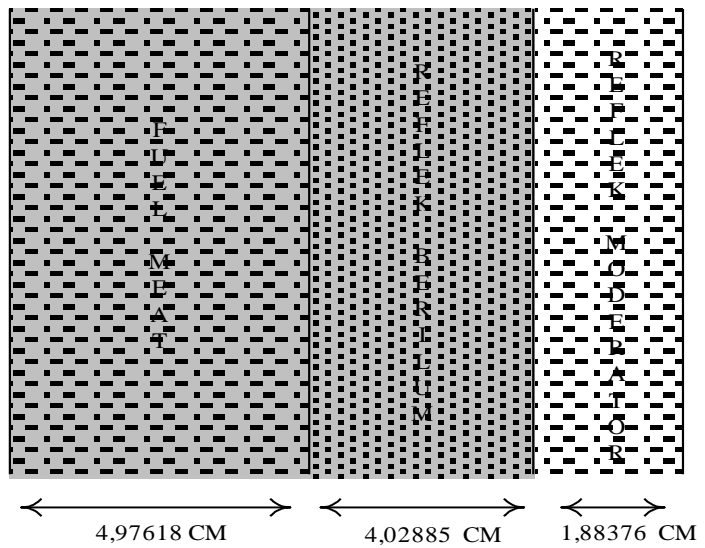

Gambar 3. Pemodelan teras setimbang RSG-GAS

Perhitungan kecepatan neutron rerata tidak seperti dalam pembangkitan konstanta makroskopik $\sum_{\mathrm{f}}$ yang dinyatakan dalam 4 kelompok energi neutron, penentuan kecepatan rerata neutron dilakukan dalam 69 kelompok energi neutron.

\subsection{Perhitungan Difusi Neutron (Batan- 2DIFF)}

Paket program Batan-2DIFF merupakan paket program untuk perhitungan teras reaktor nuklir berdasarkan teori difusi neutron banyak kelompok dengan 2 dimensi. Paket program Batan-2DIFF ditulis dalam bahasa FORTRAN dan dioperasikan di komputer pribadi $(P C)$. Data masukan untuk perhitungan teras dengan program Batan-2DIFF merupakan tampang lintang makroskopik yang telah dihitung dengan program WIMSD-5B, geometri teras dan data neutron kasip, sebagian dari opsi perhitungan atau nilai yang digunakan sebagai masukan di dalam perhitungan dinyatakan dalam Tabel 6 .

Tabel 6. Data masukan paket program Batan-2DIFF

\begin{tabular}{|l|l|}
\hline Lebar reaktor ke arah-X $(\mathrm{cm})$ & 235,7 \\
\hline Lebar reaktor ke arah-Y $(\mathrm{cm})$ & 342 \\
\hline Jumlah mesh ke arah-X & 100 \\
\hline Jumlah mesh ke arah-Y & 125 \\
\hline Jumlah kelompok tenaga & 4 \\
\hline Geometri reactor & persegi panjang \\
\hline Kondisi syarat batas kiri, kanan, atas dan bawah & Vakum \\
\hline Tampang lintang makroskopis fisi $\left(\sum_{\mathrm{f}}\right)$ & Lampiran \\
\hline Daya reaktor $(\mathrm{MW})$ & 30 \\
\hline Buckling ke arah aksial $\left(\mathrm{cm}^{-2}\right)$ & $1,764 \times 10^{-3}$ \\
\hline Jumlah iterasi luar maksimum & 500 \\
\hline Jumlah iterasi dalam maksimum & 10 \\
\hline Kriteria konvergensi $\mathrm{k}_{\mathrm{eff}}$ & $10^{-5}$ \\
\hline Kriteria konvergensi fluks neutron & $10^{-5}$ \\
\hline
\end{tabular}

Program Batan-2DIFF menggunakan subroutine DIFF untuk menyelesaikan persamaan di atas untuk menghitung nilai pribadi $\left(k_{\mathrm{eff}}\right), \quad \phi$ dan $\phi^{*}$. Kemudian subroutine ADJOINT menghitung 
parameter kinetik teras. Hasil perhitungan disusun oleh subroutine PRINT.

Parameter kinetika reaktor yang diperlukan dalam penelitian ini adalah fraksi neutron kasip efektif $\left(\beta_{\mathrm{k}}\right)$, konstanta peluruhan inti penghasil neutron kasip $\left(\lambda_{\mathrm{k}}\right)$, waktu generasi neutron serempak $(\Lambda)$ dan umur neutron rerata $\left(\ell_{\mathrm{p}}\right)$. Nilai batas parameter kinetik seperti fraksi neutron kasip efektif $\left(\beta_{\text {eff }}\right)$ adalah $\beta_{\text {eff }}=\gamma \beta^{9)}[$ Das 1993], dimana nilai $\gamma=1,05-1,25$ dan nilai $\beta=0,0064$. Jadi nilai fraksi neutron kasip yang dihasilkan harus dalam rentang tersebut yaitu 0,0672-0,008. Diluar nilai ini maka parameter kinetik $\beta$ akan ditolak.
Program
Batan-2DIFF
juga

digunakan dalam perhitungan laju produksi dan bocoran neutron pada awal dan akhir siklus untuk teras setimbang RSG-GAS. Hasilnya digunakan untuk mengoreksi kecepatan rerata neutron yang dipakai sebagai masukan untuk perhitungan parameter kinetik pada awal dan akhir siklus. Diagram alir perhitungan Batan2DIFF dapat dilihat pada Gambar 4. Keluaran dari program WIMSD-5B seperti konstanta difusi, sigma fisi dan kecepatan neutron rerata setiap nuklida serta geometri teras dan data neutron kasip material inti. Hasil perhitungan sangat sensitif terhadap data masukan seperti tampang lintang makroskopik hasil hitungan WIMSD-5B.

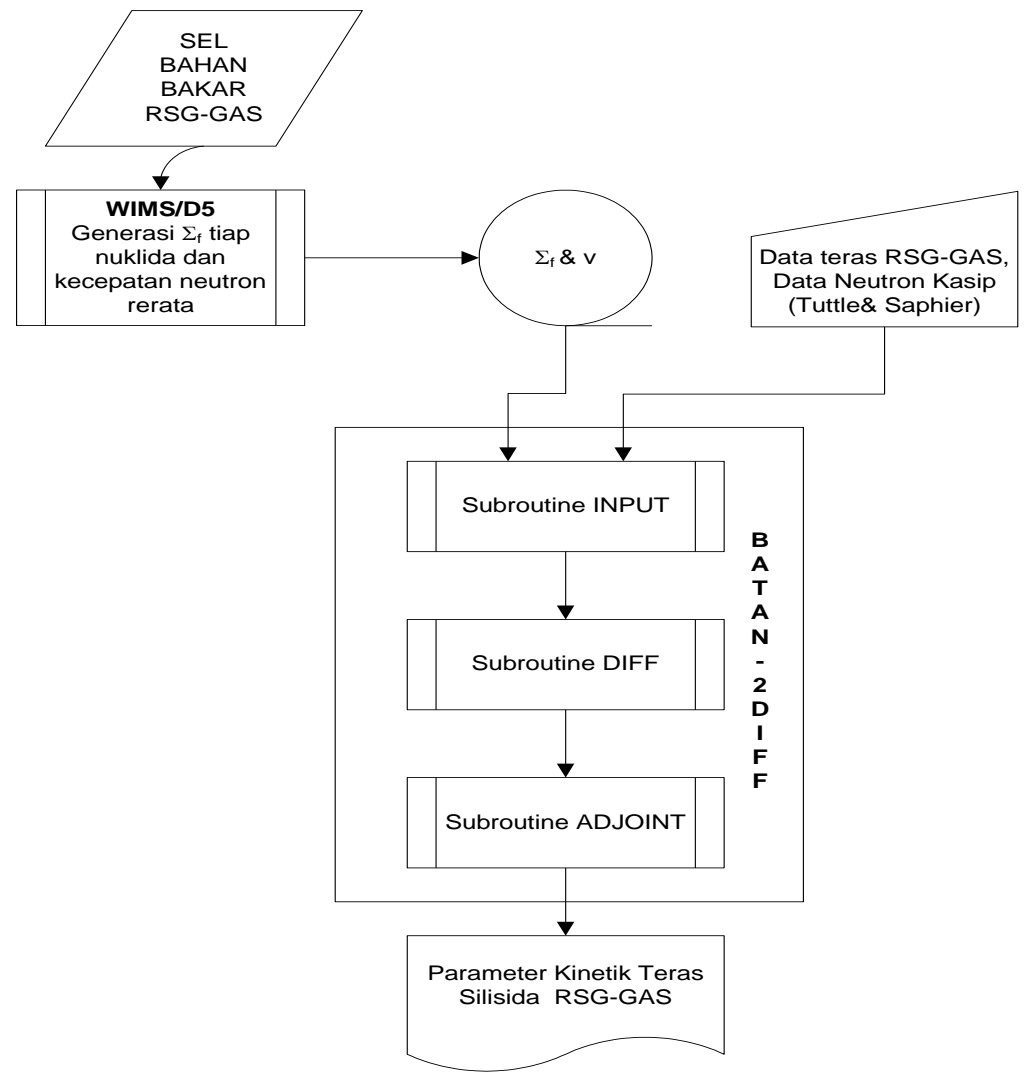

Gambar 4. Diagram Alir Batan-2DIFF

Langkah pertama adalah melakukan validasi program Batan-2DIFF pada teras transisi pertama yang terdiri dari 12 elemen bakar dan 6 elemen kendali dan bahan bakar uranium oksida semuanya baru dengan densitas 2,96 $\mathrm{gU} / \mathrm{cm}^{3}$. Kemudian dilakukan perhitungan parameter kinetik teras kerja (TWC) dengan densitas bahan bakar oksida dan silisida $2,96 \mathrm{gU} / \mathrm{cm}^{3}$. Hasil perhitungan kemudian dianalisis berdasarkan parameter 
kinetika reaktor yang sudah ada di dalam SAR (Safety Analysis Report ${ }^{10)}[$ Batan 1987] dan juga hasil eksperimen yang ada. Salah satu faktor yang sangat dibutuhkan dalam perhitungan ini adalah fraksi bakar teras RSG-GAS. Setelah hasil perhitungan parameter kinetika reaktor RSG-GAS awal siklus teras setimbang $2,96 \mathrm{~g} / \mathrm{cm}^{3}$ tervalidasi dengan baik dilanjutkan dengan langkah kedua yaitu perhitungan parameter kinetika reaktor RSG-GAS untuk teras akhir siklus dengan pola manajemen bahan bakar 5/1 dengan densitas yang sama. Pola 5/1 artinya setiap akhir siklus diganti 5 bahan bakar dan 1 elemen kendali. Selanjutnya dilakukan perhitungan parameter kinetik teras silisida dengan kerapatan bahan bakar muatan tinggi. Densitas bahan bakar tinggi yang dipilih adalah $3,55 \mathrm{gU} / \mathrm{cm}^{3}$ dan 4,80 $\mathrm{gU} / \mathrm{cm}^{3}$. Perhitungan parameter neutron kasip reaktor RSG-GAS dilakukan dengan paket progam difusi neutron 2-dimensi Batan-2DIFF. Teras silisida dimodelkan dalam geometri 2-dimensi X-Y. Perhitungan parameter neutron kasip dilakukan dalam 4 kelompok tenaga neutron. Dalam paket progam Batan-2DIFF dilakukan perhitungan nilai pribadi $\left(k_{\text {eff }}\right)$, distribusi fluks reguler dan adjoint. Subroutine ADJOINT dalam program Batan-2DIFF melakukan perhitungan parameter neutron kasip teras silisida. Data masukan yang diperlukan oleh subprogram ini adalah distribusi fluks neutron regular dan adjoint, kecepatan rerata neutron, data neutron kasip dan tampang lintang makroskopis pembelahan sebagai fungsi isotop penyusun bahan bakar silisida, Dengan data tersebut, subprogram dapat menentukan fraksi neutron kasip efektif $\left(\beta_{\text {eff }}\right)$, konstanta peluruhan neutron serempak $(\lambda)$, dan umur neutron serempak $(\Lambda)$.

\section{HASIL DAN PEMBAHASAN}

Untuk membuktikan bahwa program komputer yang digunakan valid dan pemodelan yang dibuat akurat maka dilakukan validasi dengan data teras pertama RSG-GAS, karena teras pertama masih baru dan dingin serta fraksi bakar nol. Hasil perhitungan parameter kinetik teras pertama dapat dilihat pada Tabel 7. Hasil perhitungan ini merupakan keluaran dari paket program Batan-2DIFF pada kodisi teras awal siklus (BOC). Dari tabel tersebut terlihat bahwa harga fraksi neutron kasip efektif total pada awal siklus adalah $7,695 \times 10^{-3}$, konstanta peluruhan neutron kasip rerata adalah $4,391 \times 10^{-1} \mathrm{~s}^{-1}$ dan umur rerata neutron serempak adalah $61,97 \times 10^{-6}$ s.

Tabel 7. Harga parameter kinetik teras pertama awal siklus

\begin{tabular}{|c|c|c|}
\hline Kelompok & $\beta_{\mathrm{k}}$ & $\lambda_{\mathrm{k}}\left(\mathrm{s}^{-1}\right)$ \\
\hline 1 & $2,96085 \times 10^{-4}$ & $1,27006 \times 10^{-2}$ \\
\hline 2 & $1,62717 \times 10^{-3}$ & $3,17017 \times 10^{-2}$ \\
\hline 3 & $1,45466 \times 10^{-3}$ & $1,15179 \times 10^{-1}$ \\
\hline 4 & $3,11958 \times 10^{-3}$ & $3,11431 \times 10^{-1}$ \\
\hline 5 & $9,93244 \times 10^{-4}$ & 1,40031 \\
\hline 6 & $2,04452 \times 10^{-4}$ & 3,88170 \\
\hline \multicolumn{3}{|c|}{$\beta_{\text {eff }}=7,695 \times 10^{-3}$} \\
\hline \multicolumn{3}{|c|}{$\Lambda=56,92 \times 10^{-6} \mathrm{~s}$} \\
\hline \multicolumn{3}{|c|}{$\ell=61,97 \times 10^{-6} \mathrm{~s}$} \\
\hline \multicolumn{3}{|c|}{$\tau=4,391 \times 10^{-1} \mathrm{~s}$} \\
\hline
\end{tabular}


Jika hasil perhitungan ini dibandingkan dengan parameter kinetika reaktor hasil perhitungan INTERATOM (SAR), seperti ditunjukkan oleh Tabel 8, maka terlihat bahwa ada perbedaan sebesar $0,59 \%$ untuk nilai $\beta_{\text {eff }}$ dan sebesar $1,09 \%$ untuk nilai umur neutron serentak $\left(\ell_{\mathrm{p}}\right)$ dan $0,48 \%$ untuk nilai alpha yaitu nilai konstanta peluruhan neutron serempak. Hal ini berarti bahwa validasi di atas menunjukkan bahwa perhitungan parameter kinetika teras pertama RSG-GAS hasil perhitungan Batan2DIFF cukup akurat karena perbedaan maksimum lebih kecil dari pada $1,1 \%$.

Tabel 8. Validasi parameter kinetik teras pertama

\begin{tabular}{|c|c|c|}
\hline Parameter Kinetik & SAR & Batan-2DIFF \\
\hline$\beta_{\text {eff }}$ & $7,650 \times 10^{-3}$ & $7,695 \times 10^{-3}(0,59 \%)$ \\
\hline$\Lambda(\mathrm{s})$ & - & $56,92 \times 10^{-6}$ \\
\hline$\ell(\mathrm{s})$ & $61,30 \times 10^{-6}$ & $61.97 \times 10^{-6}(1,09 \%)$ \\
\hline$\dot{\alpha}$ & 124,8 & $124,2(0,48 \%)$ \\
\hline
\end{tabular}

\subsection{Parameter Kinetika Teras Setimbang RSG-GAS}

Hasil perhitungan teras kerja (TWC=Typical Working Core) atau sering disebut teras setimbang RSG-GAS dapat dilihat pada Tabel 9 yang menyajikan parameter kinetika reaktor teras setimbang RSG-GAS dengan pola 5/1 untuk awal.
Dari tabel tersebut terlihat untuk elemen bakar silisida $2,96 \mathrm{~g} / \mathrm{cm}^{3}$ harga fraksi neutron kasip efektif total pada awal siklus $7,19 \times 10^{-3}$ dan pada akhir siklus $7,08 \times 10^{-3}$ dan konstanta peluruhan neutron kasip relatif adalah $7,84 \times 10^{-2}$. Nilai fraksi neutron kasip total teras silisida pada pola $5 / 1$, awal siklus ada dalam batas yang ditetapkan yaitu antara $(6,72-8,00) \times 10^{-3}$.

Tabel 9. Harga parameter kinetik teras RSG-GAS awal siklus

\begin{tabular}{|c|c|c|}
\hline Kelompok & Fraksi Neutron Kasip $\left(\beta_{\mathrm{k}}\right)$ & Konstanta Peluruhan Neutron Kasip $\left(\lambda_{\mathrm{k}}\right)$ \\
\hline 1. & $2,74 \mathrm{E}-04$ & $1,27 \mathrm{E}-02$ \\
\hline 2. & $1,53 \mathrm{E}-03$ & $3,17 \mathrm{E}-02$ \\
\hline 3. & $1,36 \mathrm{E}-03$ & $1,16 \mathrm{E}-01$ \\
\hline 4. & $2,91 \mathrm{E}-03$ & $3,12 \mathrm{E}-01$ \\
\hline 5. & $9,26 \mathrm{E}-04$ & $1,39 \mathrm{E}+00$ \\
\hline 6. & $1,92 \mathrm{E}-04$ & $3,87 \mathrm{E}+00$ \\
\hline \multicolumn{3}{|c|}{ Fraksi Neutron Kasip Total: $7,19 \times 10^{-03}$} \\
\hline \multicolumn{3}{|c|}{ Konstanta Peluruhan Neutron Kasip Total: $7,84 \times 10^{-2} \mathrm{~s}^{-1}$} \\
\hline \multicolumn{3}{|c|}{ Umur Neutron Serempak: $64,51 \mu \mathrm{s}$} \\
\hline
\end{tabular}

Tabel 10. Harga parameter kinetik teras RSG-GAS awal siklus

\begin{tabular}{|c|c|c|c|}
\hline Parameter & $2,96 \mathrm{gU} / \mathrm{cm}^{3}$ & $3,55 \mathrm{gU} / \mathrm{cm}^{3}$ & $4,80 \mathrm{gU} / \mathrm{cm} 3$ \\
\hline Fraksi neutron kasip & $7,19 \times 10^{-3}$ & $7,09 \times 10^{-3}$ & $7,03 \times 10^{-3}$ \\
\hline Umur neutron serempak (s) & $64,51 \times 10^{-6}$ & $62,81 \times 10^{-6}$ & $55,49 \times 10^{-6}$ \\
\hline $\begin{array}{c}\text { Konstanta Peluruhan neutron } \\
\text { kasip (/s) }\end{array}$ & $7,84 \times 10^{-2}$ & $7,85 \times 10^{-2}$ & $7,84 \times 10^{-2}$ \\
& & & \\
\hline
\end{tabular}


Tabel 10. Menunjukan nilai fraksi neutron kasip dan umur neutron serempak teras silisida dengan densitas 3,55 dan 4,80 $\mathrm{gU} / \mathrm{cm}^{3}$. Jika dibandingkan dengan nilai sebelumnya yaitu densitas $2,96 \mathrm{gU} / \mathrm{cm}^{3}$, maka nilainya menurun. Hal ini disebabkan karena jumlah inti atom U-238 di dalam teras bertambah besar sehingga membuat nilai fraksi neutron kasip dan nilai umur neutron serempak turun. Namun perbedaan ini tidak signifikan dan masih dalam batas yang diizinkan sehingga masih mampu untuk mengontrol operasi reaktor. Nilai fraksi neutron kasip total untuk densitas $3,55 \mathrm{gU} / \mathrm{cm}^{3}$ awal siklus ada dalam batas yang ditetapkan yaitu $(6,72-8,00) \times 10^{-3}$.

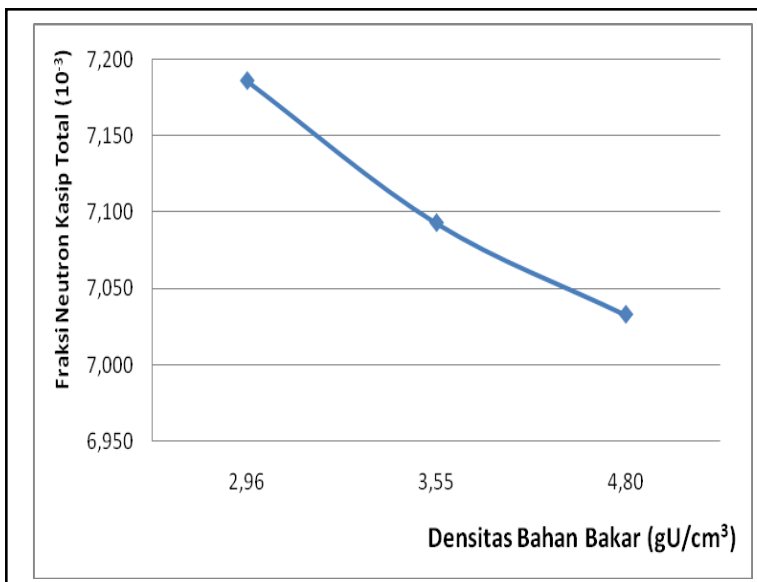

Gambar 6. Hubungan nilai fraksi neutron kasip fungsi densitas bahan bakar

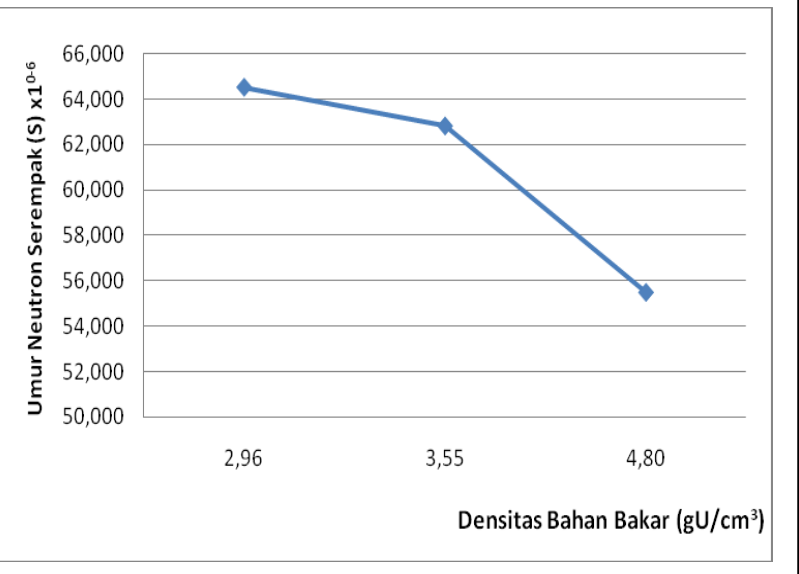

Gambar 7. Hubungan nilai umur neutron serempak terhadap densitas
Nilai fraksi neutron kasip total teras silisida densitas $4,8 \mathrm{~g} \mathrm{U} / \mathrm{cm}^{3}$ juga terdapat pada Tabel 10. Nilai fraksi neutron kasip efektif total $7,03 \times 10^{-03}$ dan konstanta peluruhan neutron kasip $7,84 \times 10^{-02} \mathrm{~s}^{-1}$. Jika dibandingkan dengan silisida kerapatan 2,96 $\mathrm{g} \mathrm{U} / \mathrm{cm}^{3}$ dan $3,55 \mathrm{gU} / \mathrm{cm}^{3}$ nilainya menurun namun perbedaannya tidak signifikan. Nilai umur neutron serempak untuk silisida 4,8 $\mathrm{gU} / \mathrm{cm}^{3}$ adalah $55,49 \mu$ s dan teras silisida $2,96 \mathrm{gU} / \mathrm{cm}^{3}$ sebesar $64,51 \mu \mathrm{s}$. Nilai fraksi neutron kasip efektif total dan konstanta peluruhan neutron kasip hampir sama dibandingkan dengan silisida 2,96 $\mathrm{g} \mathrm{U} / \mathrm{cm}^{3}$ dan $3,55 \mathrm{gU} / \mathrm{cm}^{3}$ Namun nilai umur neutron serempak berkurang sekitar 2,7 \%. Penurunan ini diakibatkan bertambahnya inti U-238 di dalam bahan bakar dalam teras dimana terbentuknya plutonium dan hasil fisi dalam teras reaktor akan menyerap neutron dengan cepat. Namun Nilai fraksi neutron kasip total untuk densitas ini juga masih dalam batas aman yang ditetapkan yaitu $(6,72-8,00) \times 10^{-3}$.

Gambar 6 dan 7 menunjukkan bahwa nilai fraksi neutron kasip total dan umur neutron di dalam teras turun secara signifikan namun utuk menambah penjang siklus operasi harus ada konsekuensi yang ditanggung yaitu pengontrolan reaktor agak lebih hati hati dibandingkan dengan densitas rendah, sehingga hasil penelitian ini boleh digunakan untuk dasar mengambil keputusan.

\section{KESIMPULAN}

Hasil perhitungan menunjukkan bahwa harga fraksi neutron kasip dan umur neutron serempak turun dengan bertambahnya fraksi bakar dalam teras dengan jenis dan densitas bahan bakar yang sama. Dari hasil tersebut terlihat bahwa dengan penurunan parameter 
kinetik akibat pergantian bahan bakar dari oksida 2,96 $\mathrm{gU} / \mathrm{cm}^{3}$ ke silisida $2,96 \mathrm{gU} / \mathrm{cm}^{3}$ tidak memberikan pengaruh yang signifikan terhadap operasi reaktor RSG-GAS. Namun dengan naiknya densitas bahan bakar berarti akan meningkatkan panjang siklus operasi reaktor membuat reaktor lebih ekonomis. Nilai fraksi neutron kasip dan umur neutron serempak turun dengan bertambahnya densitas. Ini disebabkan bertambahnya material teras sehingga neutron cepat terserap oleh material di dalam teras reaktor sehingga umur rerata neutronnya berkurang. tetapi penurunannya tidak begitu signifikan sehingga keselamatan operasi reaktor masih dalam batas yang diizinkan. Namun dengan lebih tingginya densitas bahan bakar secara keseluruhan menyebabkan lebih kecilnya fraksi neutron kasip sehingga perlu lebih hati-hati untuk mengontrol operasi reaktor jika dibandingkan dengan densitas yang lebih rendah. Ditinjau dari segi neutronik dan kinetik maka penggantian elemen bakar silisida kerapatan $2,96 \mathrm{gU} / \mathrm{cm}^{3}$ ke silisida dengan kerapatan $3,55 \mathrm{gU} / \mathrm{cm}^{3}$ atau 4,8 $\mathrm{gU} / \mathrm{cm}^{3}$ dapat dilakukan tanpa mengubah pola manajemen bahan bakar di dalam teras sehingga pola operasi reaktor RSG-GAS tetap seperti sekarang.

\section{DAFTAR PUSTAKA}

[1] LIEM P.H, ARBIE B, TAGOR M.S, PRAYOTO P, NABBI R," Fuel Management Strategy for The New Equilibrium Silicide Core Design of RSG-GAS" Nuclear Engineering and Design, Vol. 180, No 3 (1998).

[2] TUKIRAN S, dan ZUHAIR , "Perhitungan Parameter Kinetik Teras RSG-GAS Berbahan Bakar Silisida", Prosiding Seminar Teknologi dan Keselamatan PLTN serta Fasilitas Nuklir-V, Jakarta, (1998).
[3] TUKIRAN S," Koefisien Reaktivitas dan Reaktivitas Xenon Teras RSGGAS", Bahan Mengajar pada Diklat Selingkung Manajemen Teras RSGGAS di Pusbang Teknologi Reaktor Riset, Serpong, 18 Okt. 1999 - 11 Feb. (2000)

[4] TUKIRAN S, TAGOR M.S, SURIAN P, “ Analisis Spektra Energi Neutron Kasip Dalam Perhitungan $\beta_{\text {eff }}$ di Teras RSG-GAS", Proseding Simposium Fisika Nasional XVIII, DRN Puspiptek Serpong 25-27 April (2000).

[5] FARHAN M, and ASAD MAJID," Kinetic Parameters of a Material test Research Reactor Fueled with high Density $\mathrm{U}_{3} \mathrm{Si}_{2}$ Dispersion Fuels". Annals of Nuclear Energy 51, (2009)

[6] TUKIRAN S," Analisis Kecelakaan Reaktivitas Teras RSG-GAS Berbahan Bakar Silisida", Prosiding Seminar Ke7, Teknologi dan Keselamatan PLTN Serta Fasilitas Nuklir, ISSN: 0854-2910, Bandung, 19 Februari (2002).

[7] TUKIRAN S, dan TAGOR M.S," Analisis Neutronik Teras RSG-GAS Berbahan Bakar Silisida" , Prosiding Kontribusi Fisika Indonesia, ISSN: 0854-6878, HFI, FMIPA-Fisika, ITBBandung, Vol. 12, No. 3, (1998).

[8] LILY S, "Kajian Desain Konfigurasi Teras Reaktor Riset Untuk Persiapan Rancangan Reaktor Riset Baru di Indobesia" Prosiding Seminar PPIPDIPDT PTAPB-Yogyakarta (2011)

[9] DAS S., "Important of Delayed Neutrons in Nuclear Research" Theoritical Physics Division, Bhabha Atomic Research Centre< Bombay, India (1993)

[10] BATAN, "Safety Analysis Report Rev. 7', Batan, Jakarta (1987). 